\title{
GEOCHEMICAL AND CHEMOSTRATIGRAPHIC ASSESSMENT OF THE ALBIAN-OLIGOCENE INTERVAL OF THE NORTHERN PORTION OF SANTOS BASIN
}

\author{
AVALIAÇÃO GEOQUÍMICA E QUIMIOESTRATIGRAFIA DO INTERVALO ALBIANO- \\ OLIGOCENO DA PORÇÃO NORTE DA BACIA DE SANTOS
}

\author{
Marcus Vinicius Berao ADE, Natalia Madeiros Marins NUNES, Rene RODRIGUES, \\ Fernanda Botelho de ASSIS, Felipe NASCIMENTO, Ricardo Teixeira Nicaceo LEITE \\ Universidade do Estado do Rio de Janeiro. Emails: marcus.ade@uerj.br; natmarins@hotmail.com; rene@uerj.br; \\ fernandabassis@gmail.com; fenascimento@qgep.com.br; nicacio.1@gmail.com
}

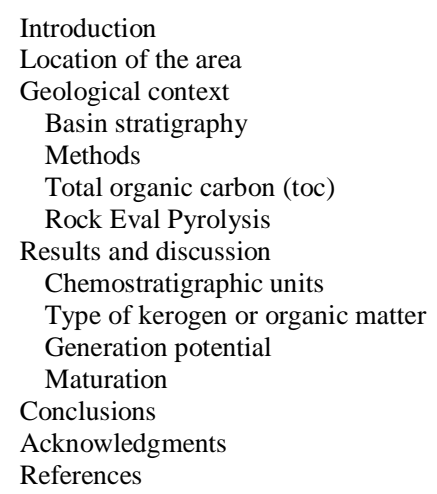

\begin{abstract}
RESUMO - O estudo geoquímico de rochas, na indústria do petróleo, é uma eficiente ferramenta utilizada para caracterização do conteúdo orgânico das rochas e possíveis geradoras. Nas últimas décadas começou a ser utilizada como uma ferramenta para estratigrafia química mostrando excelentes resultados. A análise dos dados de carbono orgânico total, resíduo insolúvel e resultados de pirólise como índice de hidrogênio, pico $\mathrm{S}_{1}$ (hidrocarbonetos gerados) e pico $\mathrm{S}_{2}$ (hidrocarbonetos gerados pela pirólise), disponíveis em seis poços, resultou na identificação de quatro unidades quimioestratigráficas denominadas A, B, C e D na porção norte da Bacia de Santos. A matéria orgânica das unidades A e D foi caracterizada como tipo III e as unidades B e C como uma mistura II/III. As unidades B e C mostraram-se com potencial pra geração porem imaturas nesta área. Estas unidades potencialmente geradoras entrariam na janela de geração a profundidade de 5000m.

Palavras-chave: pirólise; estratigrafia química; matéria orgânica; maturação.
\end{abstract}

\begin{abstract}
The geochemical study of rocks, in the oil industry, is an efficient tool utilized for characterizing the organic content of rocks and possible source rocks. In the last decades it began to be used as a tool for chemical stratigraphy showing excellent results. The data analysis of total organic carbon, insoluble residue and pyrolysis results as hydrogen index, peak $\mathrm{S}_{1}$ (generated hydrocarbons) and peak $S_{2}$ (hydrocarbons generated by pyrolysis), in six wells, resulted in the identification of four chemostratigraphic units, denominated A, B, C and D in the northern portion of the Santos Basin. The organic matter of units A and D was characterized as type III and units B and C as a mixture II / III. Units B and C showed potential for immature generation in this area. These potentially generating units would in the generation window at a depth of $5000 \mathrm{~m}$.
\end{abstract}

Keywords: pyrolysis; chemical stratigraphy; organic matter; maturation.

\section{INTRODUCTION}

Exploration in Santos Basin began in the 1970s, initially without satisfactory results in relation to the identification of hydrocarbon accumulations. The first discovery occurred in 1980, by Pecten, in turbiditic sandstones of the Itajaí-Açu Fm, Merluza Field (Pereira \& Macedo, 1990). With the discovery of Tubarão, Coral, Estrela do Mar, and Caravela fields, starting in the 1980s, the Santos Basin became a promising area, confirmed in the last few years, with the discovery of Mexilhão, Tupi and Júpiter.

Organic geochemistry has long been effectively utilized as an exploration tool, since it aids in the identification of possible source rocks and their relation with known prospects. The techniques associated with this field of the geosciences study the existing organic content in rocks, qualitatively, quantitatively, in relation to their potential source, thermal evolution stage and also correlates hydrocarbon accumulations to the corresponding source rock of origin.

This work analyzed and interpreted the geochemical results in six wells, furnished by ANP- Agência Nacional de Petróleo, Gás Natural e Biocombustíveis (the national petroleum agency in Brazil):1-BSS-0069-BS, 3-BRSA-2A-RJS, 3-BRSA-19-RJS, 1-BRSA74B-RJS, 1-BRSA-102-RJS and 1-RJS-0539$\mathrm{RJ}$, located in the northern portion of the Santos Basin. 


\section{LOCATION OF THE AREA}

The Santos Basin is located in the southeastern portion of the Brazilian continental margin. The physiographic elements - Serra do Mar Range (continental) to the West; Santonian/Campanian Cabo Frio Volcanic Arch (Cabo Frio High) to the North; Florianópolis High to the South; and São Paulo Plateau (bathymetry down to $3000 \mathrm{~m}$ ) to the
East - are the geological markers that geographically limit the Santos Basin depression, with an area of $350,000 \mathrm{~km}^{2}$ (Mohriak, 2003,). The wells utilized in this assessment are close to the boundary with Campos Basin (Cabo Frio High) and their postsalt sedimentary package was the focus of this study (Figure 1).

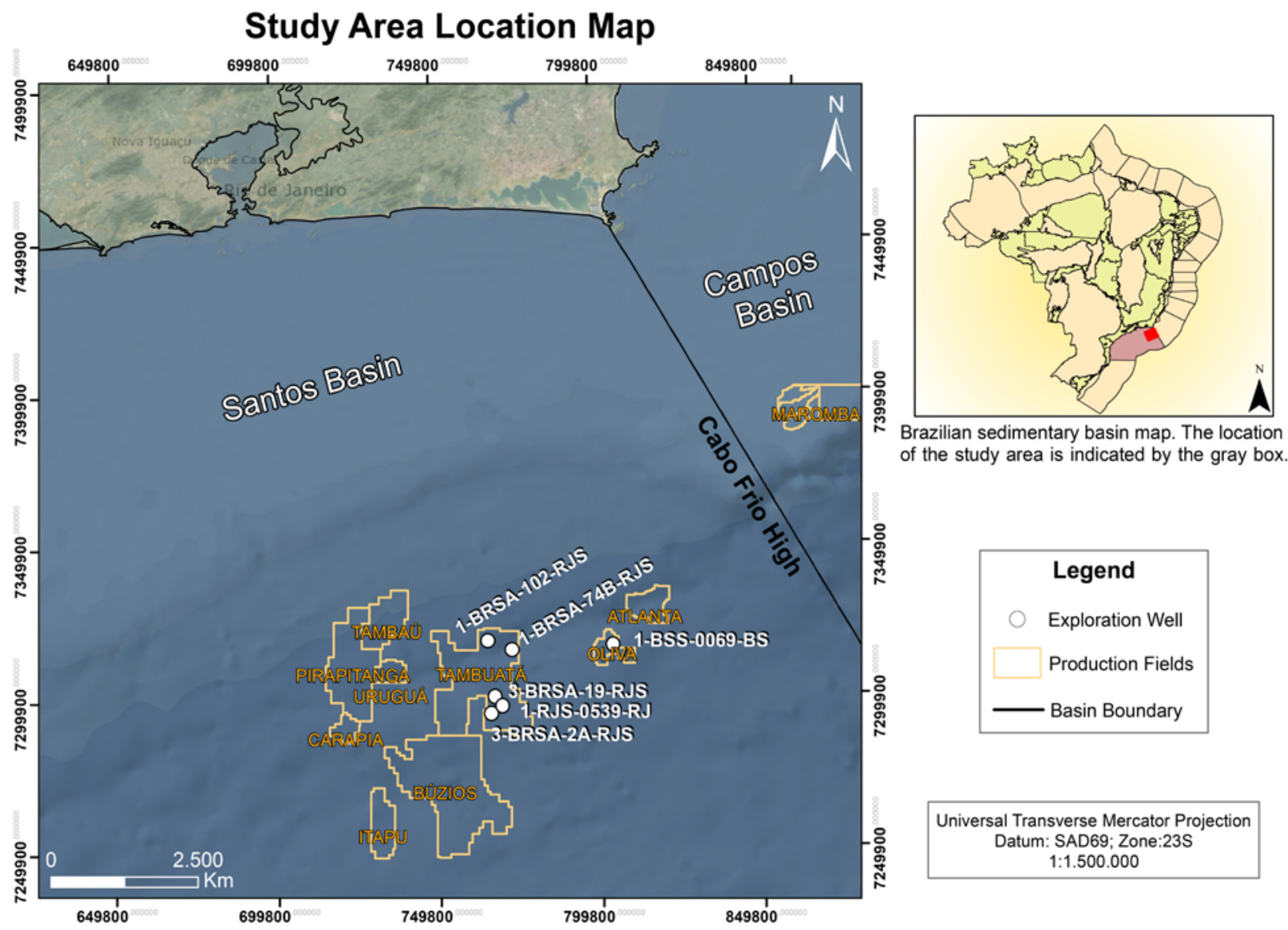

Figure 1 - Study area location map (modified from Almeida, 1986).

\section{GEOLOGICAL CONTEXT}

The genesis of the Santos Basin, according to Chang et al. (1990) and Moreira et al. (2007), as well as that of all the basins of the eastern Brazilian continental margin, is associated with extensional stresses that caused the rupture of the Gondwana Continent and the separation of South America and Africa. These distensive stresses were responsible for the crustal thinning and consequent rupture, causing rifting of the continental crust during the Hauterivian and lasting until the Aptian. Continental deposits of alluvial fans on the edges, grading to lacustrine and lagoonar towards the basin, filled the accommodation spaces created. The post-rift phase (Aptian) is characterized by a tectonic quiescence with predominant thermal subsidence, and deposits typical of stressful shallow water conditions (microbial deposits, stromatolites and evaporites).

As the evaporitic deposits were drowned, a new drift phase began, and the South Atlantic Ocean set in. This phase is still ongoing, and shallow platform, slope, and deep-water deposits occur.

\section{Basin stratigraphy}

Moreira et al. (2007) subdivides the sedimentary package of the basin into tectonic phases: Rift (Hauterivian - Lower Aptian), Post-Rift (Aptian) and Drift (Albian present). In light of the sequence stratigraphy 
of the sedimentary package of Santos Basin, 25 second order sequences were identified.

The upper and lower limits of these intervals are marked by erosive unconformities and/or their relative conformities (Figure 2).

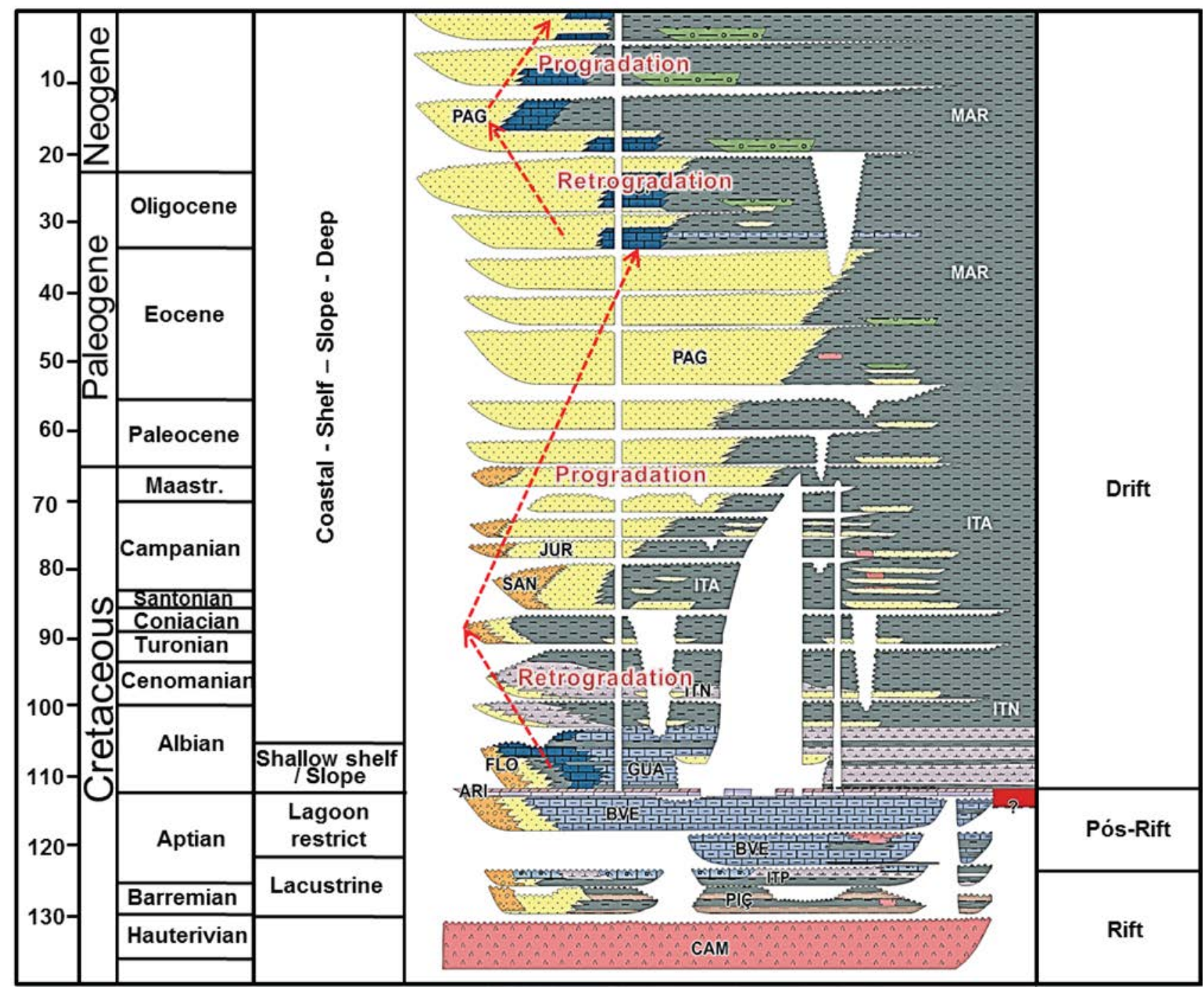

Figure 2- Stratigraphic chart of Santos Basin (modified from Moreira et al., 2007).

The Rift phase (Hauterivian -Lower Aptian), according to Moreira et al.(2007), is characterized by basaltic lava flows throughout the basin, associated with start of the fracturing and faulting of the South America -Africa separation. This package is overlain by the alluvial fan sequence with conglomerates and polymictic sandstone in the proximal portions, and lacustrine with politic deposits towards the center of the basin. At the end of the rift phase, proximal sandy, conglomeratic deposits of alluvial fans occur, changing laterally to calcirudites (coquinas) and shale rich in organic matter (source rock) in the depocenters of a lacustrine environment.

The Post-Rift Aptian age phase, also known as SAG (Chang et al., 1990), is characterized in the basal portion by the predominance of carbonatic rocks (mudstone, microbialites, stromatolites, grainstone and packstone proximal) and by distal shales deposited in a transitional environment (shallow marine to continental). The top (Neoaptian) corresponds to evaporitic deposits where the evaporation rate is more than the rate of water entry into the restricted marine environment. The predominant evaporitic minerals are halite and anhydrite, and to a lesser extent, tachyhydrite, and locally, sylvite. According to Pereira et al. (1986), Macedo (1989) and Moreira et al. (2007), the evaporitic package was overlain by an Albian basal sequence, establishing the effective separation of the continents, as the meso-oceanic chain developed and the sea made a definitive entry.

The Drift phase, interval which the six wells analyzed herein penetrate, includes the 
temporal interval from the Albian to the present. In this phase, the sedimentary package can be grouped into two major retrogradingprograding sets. The first occurs from the Albian to the Neo-Eocene, and the second from the Eoneocene to the present (Figure 2).

According to Quintaes (2006, apud Moreira et al., 2007), the Albian-Coniacian interval exhibits the retrograding depositional character composed of alluvial and deltaic fan deposits on the western edge (conglomerates, sandstones and pelites), grading to a carbonatic platform to east. In the shallow portion of this carbonatic platform, calcarenites and calcirudites occur on shallow banks, and calcilutites and shales in the lagoonar system. In the external portion, calcilutites, marls interleaved with shales rich in organic matter, predominate.

The calcilutites associated with organisms from neritic environments signal a strong subsidence in the carbonatic platform (Chang et al., 2008). Marine shales from deeper waters cover the shallow water marls that overlie the proximal sandstones. On the slope, sandy, channeled hyperpycnal deposits occur, which lose part of their confinement towards the basin, generating unconfined/spreading deposits (Moreira et al., 2007).

The sedimentary package between the Santonian and the Eocene exhibit a strongly prograding character, evidenced by the thick, mainly sandy package, that advances basinward over the pelitic material (mainly shales). This sedimentary set may be associated with the strong uplift movement of the western margin, Serra do Mar Range, (Almeida, 1976 apud Macedo, 1989). In this interval, sandy alluvial, fluvial and coastal proximal deposits predominate, sometimes reddish, laterally grading to platform and slope deposits, mainly of pelitic composition. Sandy bodies are deposited in the basinal portion through hyperpycnal flows. Gravitational flows due to slope instability, when the relative sea level falls, generate diamictite bodies in the distal portions of the slope (Moreira et al., 2007).

The start of the second retrogradingprograding set, a sedimentary OligoceneMiddle Miocene package, exhibits a retrograding character with a reduction in the volume of sandstone, and a significant increase in pelites towards the continent. This may be associated, according to Pereira et al. (1986) and Macedo (1989), to the reduction in the deposition of sediments, due to the displacement of the sedimentary discharge towards another depocenter, because of the migration of the Paraiba do Sul River outfall towards Campos Basin (northward).

According to Moreira et al. (2007), this retrogradation is associated with a great rise in the relative sea level. The deposicional facies of this interval are sandy, alluvial, fluvial and coastal proximal deposits, sometimes reddish, laterally grading to shallow platform deposits with calcarenite and calcirudite. In the slope, the dominant composition pelitic, associated, secondarily, with sandy bodies deposited in the basinal portion, through hyperpycnal flows. Finally, the second set, the Middle MiocenePleistocene interval, exhibits a prograding character, with basinward displacement of the sand over the pelites. The deposicional facies of this interval are the same as described in the retrograding phase of this second set.

\section{METHODS}

This study utilized total organic carbon and Rock-Eval Pyrolysis.

\section{Total Organic Carbon (TOC)}

The total organic carbon content (TOC) reflects, in weight, the quantity of organic matter present in the sedimentary rock. It is, in turn, the final result of the interaction between factors such as the quantity of available biomass for accumulation, the sedimentation rate in the deposicional location, the preservation degree of the biomass during its deposition and early diagenesis (Tissot \& Welte, 1984).
Subsequently, the TOC is influenced by sedimentary burial and the reactions responsible for the transformation of organic matter into petroleum, which progressively reduces its values throughout catagenesis and metagenesis (Tissot \& Welte, 1984). In general, it is accepted that sedimentary rocks must have TOC values over $1 \%$ in order to be considered potential source rocks for petroleum (Peters \&

\section{Rock Eval Pyrolysis}

The Rock Eval Pyrolysis process performed in bulk rock is utilized to characterize the type Cassa, 1994). 
of kerogen, thermal maturation level, and the generation potential present in the rocks. The technique presented by Espitalié et al. (1977), simulates the thermal alteration process of the kerogen in the absence of oxygen. In this process, approximately $100 \mathrm{mg}$ of sample rock is submitted to temperatures between $300^{\circ} \mathrm{C}$ and $550^{\circ} \mathrm{C}$, at a temperature increase rate of $25^{\circ} \mathrm{C} /$ minute. A flame ionization detector captures all hydrocarbons generated during pyrolysis, which are represented by two peaks, $\mathrm{S}_{1}$ and $\mathrm{S}_{2}$ (in $\mathrm{mg}$ of hydrocarbons/g of rock), and an infrared detector indicates the $S_{3}$ peak (mg of $\mathrm{CO}_{2} / \mathrm{g}$ of rock) (Figure 3).

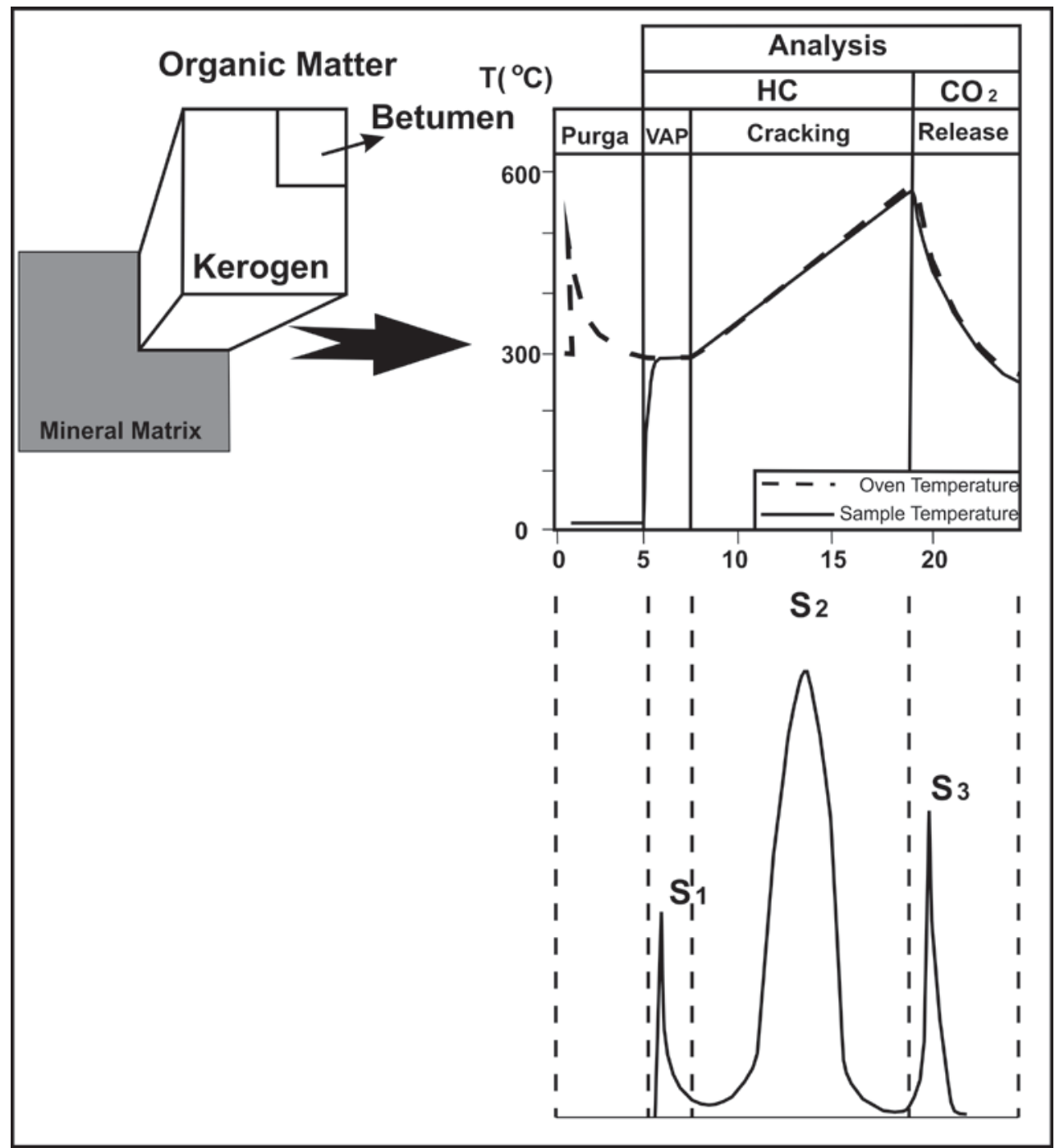

Figure 3 - Rock-Eval Pyrolysis cycle analysis an example (modified from Tissot \& Welte, 1984).

Rock Eval Pyrolysis Parameters:

1. $\mathrm{S}_{1}$ (mg HC/g rock) - represents the free hydrocarbons in the rock, that is, the quantity generated in nature, contained in the sample.

2. $\mathrm{S}_{2}$ (mg HC/g rock) - represents the hydrocarbons that were generated by pyrolysis. It indicates the generation potential of the rock, that is, the quantity of hydrocarbons that the rock can still generate if it were to be submitted to ideal temperature conditions.

3. $\mathrm{S}_{3}$ (mg CO$/ 2$ g rock) - represents the $\mathrm{CO}_{2}$ generated by the organic matter of the rock.

4. Tmax $\left({ }^{\circ} \mathrm{C}\right)$ - indicates the temperature at which the maximum quantity of hydrocarbons was generated (maximum value at $\mathrm{S}_{2}$ peak).

Utilizing $\mathrm{S}_{2}, \mathrm{~S}_{3}$ and TOC, the type of organic matter present can be determined using the Hydrogen Index (HI), obtained from the $\mathrm{S}_{2} / \mathrm{TOC}$ ratio $\mathrm{x} 100$ (mg HC/g TOC), and the Oxygen Index (OI), obtained from the $\mathrm{S}_{3} / \mathrm{TOC}$ ratio x100 (mg CO $/ \mathrm{CO}_{2} \mathrm{TOC}$ ).

These two indices correspond, approximately, to the $\mathrm{H} / \mathrm{C}$ and $\mathrm{O} / \mathrm{C}$ ratios of the elements analysis of the kerogen (Espitalié et al., 1977), and might be plotted in van Krevelen type diagrams (Figure 4), from which the organic matter is classified as being of type I, II, III or IV (Tissot \& Welte, 1984). 


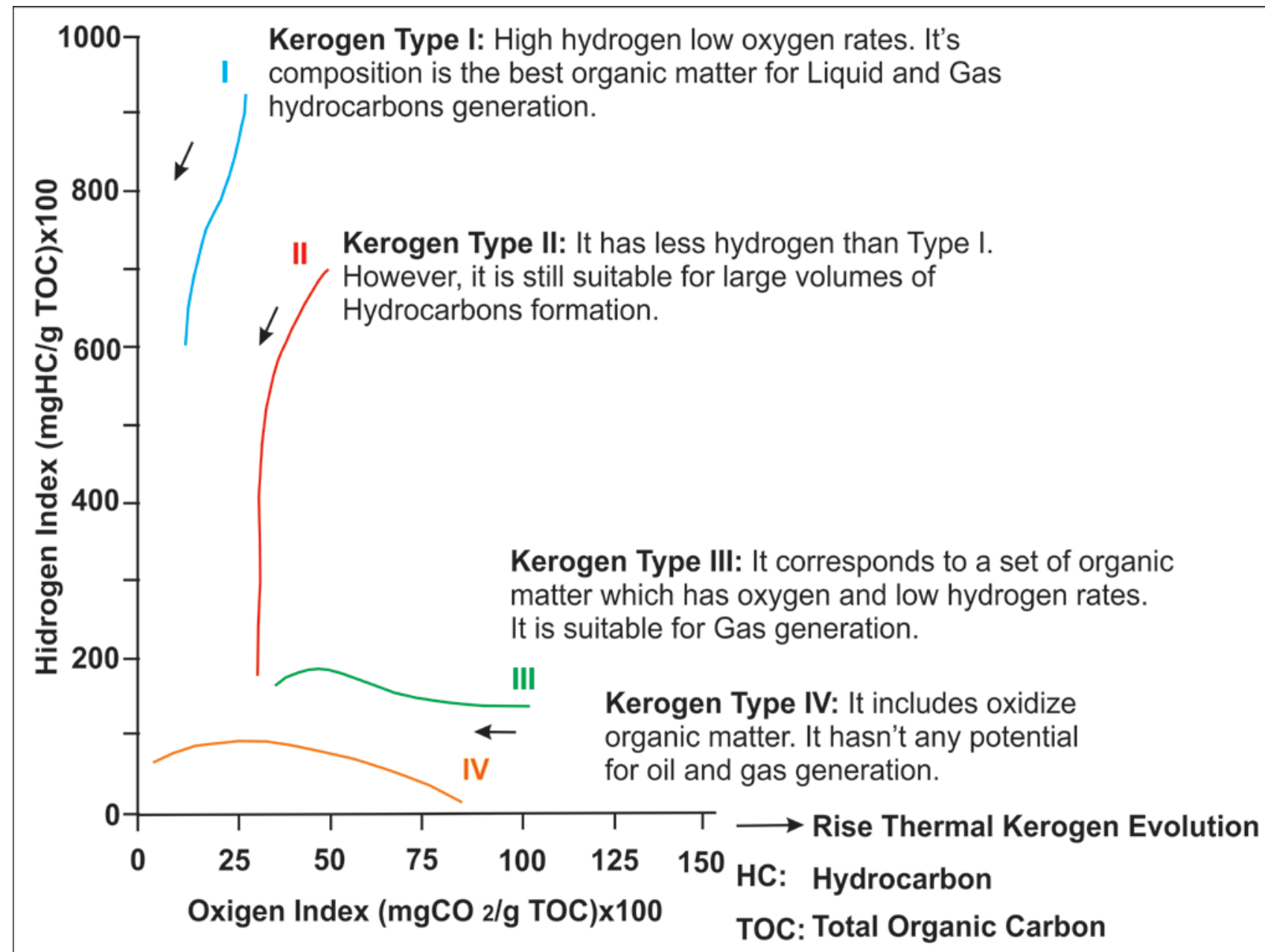

Figure 4 - Classification and thermal evolution of kerogen, second diagram type “van Krevelen” (Espitalié et al., 1985).

A semiquantitative assessment of the generation potential (mg $\mathrm{HC} / \mathrm{g}$ rock) of the organic matter present in each rock sample can be obtained utilizing the $\mathrm{HI}$ values $(\mathrm{mgHC} / \mathrm{g}$ TOC) and the $S_{2}$ peak, according to the following table (Espitalié et al., 1985):

$\mathrm{HI}<200=$ potential for gas

$200<\mathrm{HI}<300=$ potential for gas and condensate

$\mathrm{HI}>300=$ potential for oil

$\mathrm{S}_{2}<2,0=$ poor generation potential

$2,0<\mathrm{S}_{2}<5,0=$ moderate generation potential
$5,0<\mathrm{S}_{2}<10=$ good generation potential

$\mathrm{S}_{2}>10=$ excellent generation potential

The results of the TOC analyses, insoluble residue (IR) and Rock-Eval Pyrolysis of the samples from wells 1-BSS-0069-BS, 3-BRSA2A-RJS, 3-BRSA-19-RJS, 1-BRSA-74B-RJS, 1-BRSA-102-RJS, and 1-RJS-0539-RJ, furnished by ANP, were obtained from analyses performed by Petrobras.

That information was plotted diagrams showing depth (m) versus TOC, IR, Tmax, S1, S2, and HI, and in van Krevelen type diagrams.

\section{RESULTS AND DISCUSSION}

\section{Chemostratigraphic Units}

The variations in relative concentration of TOC and IR parameters reflect their susceptibility to environmental changes, which occur due to the dynamics of sedimentary filling of deposicional systems.

Low IR values (IR $<30 \%$ ) represent carbonates, values between $30 \%$ and $70 \%$ represent marls, and higher values (IR> 70\%) represent siltstones and shales. TOC higher than $1 \%$ represent dysoxic conditions and low circulated water.

Based on TOC and IR data, four chemostratigraphic units were defined: A, B, C and D (Figures 5, 6, 7, 8, 9). Only in well 1BRSA-102-RJS, it was not possible to identify and separate the data into separate chemostratigraphic units (Figure 10). 


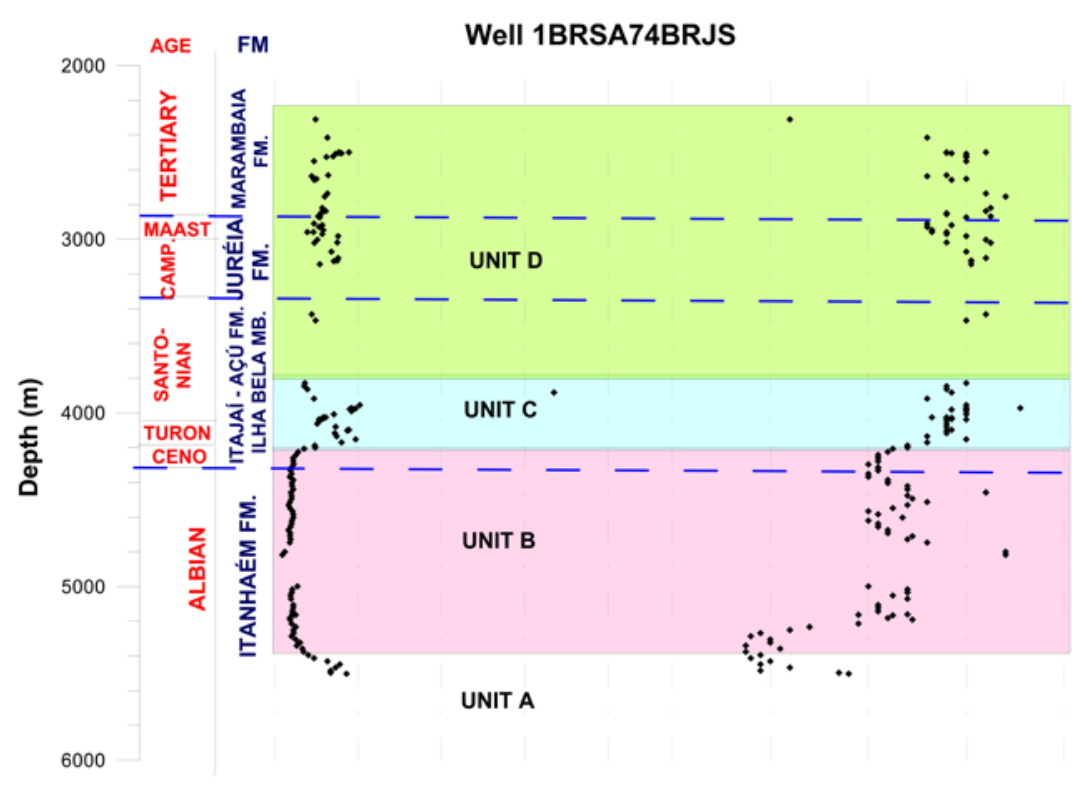

Figure 5 - Plot depicting TOC and IR versus depth for well 1-BRSA-74B-RJS, showing the four chemostratigraphic units identified.

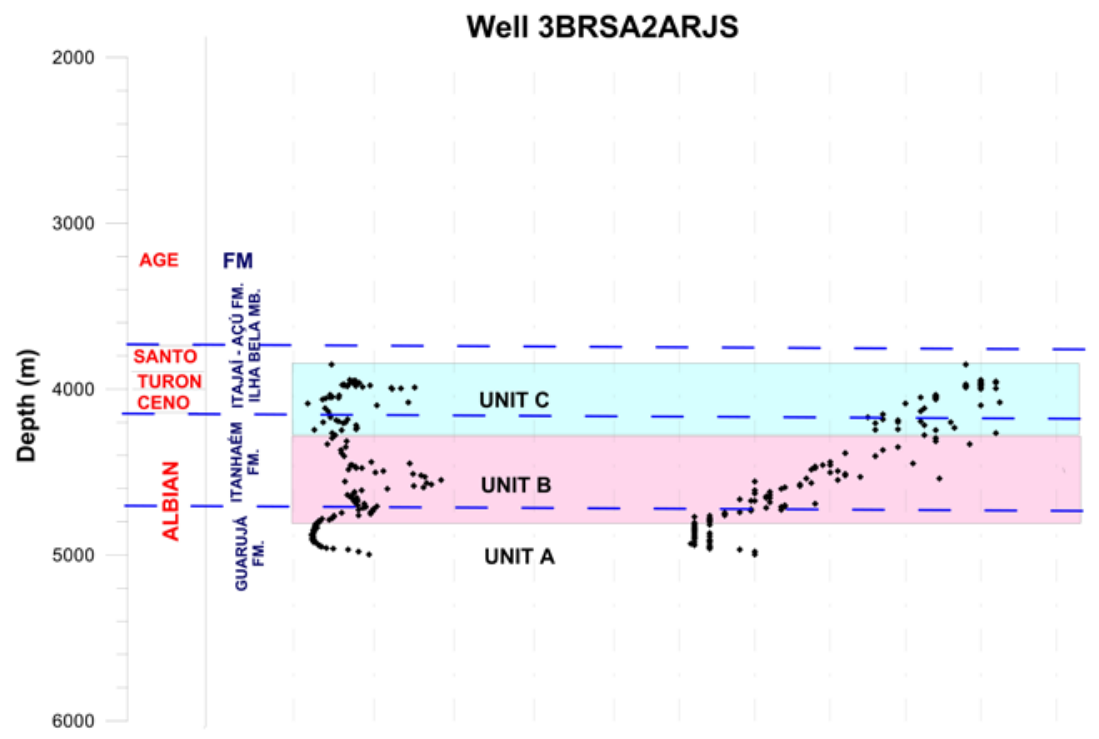

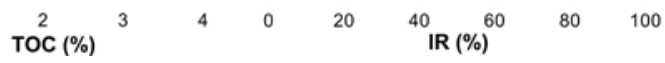

Figure 6 - Plot depicting TOC and IR versus depth for well 3-BRSA-2A-RJS, showing the three chemostratigraphic units identified.

\section{Chemostratigraphic Unit A}

Unit A, of Albian age, is characterized by TOC values between $0.3 \%$ and almost $1 \%$, and IR values between $20 \%$ and $60 \%$, except in well 3-BRS-2A-RJS, whose IR values varied from $0 \%$ to $20 \%$ (Figures 5,6 ). These values indicate that this units essentially composed of marls and carbonates. In wells 1-BSS-0069-BS and 3BRSA-19B-RJS, it was not possible to achieve a good identification of the unit (Figures 7,8 ), and in wells 1-RJS-0539-RJ and 1-BRSA-102-RJS, the unit was not identified (Figures 9, 10).

Chemostratigraphic Unit B

Unit B, also of Albian age, and inserted in the Itanhaém Fm., is characterized by TOC values approximately between $0.3 \%$ and $1 \%$, and IR values approximately between $20 \%$ and $80 \%$ (Figures 5, 7, 8, 9), except in well 3-BRSA-2ARJS, which had TOC values of up to $1.8 \%$ and IR values between $2 \%$ and $85 \%$ (Figure 6 ).

This unit, like the prior one, is essentially composed of marls and carbonates. 


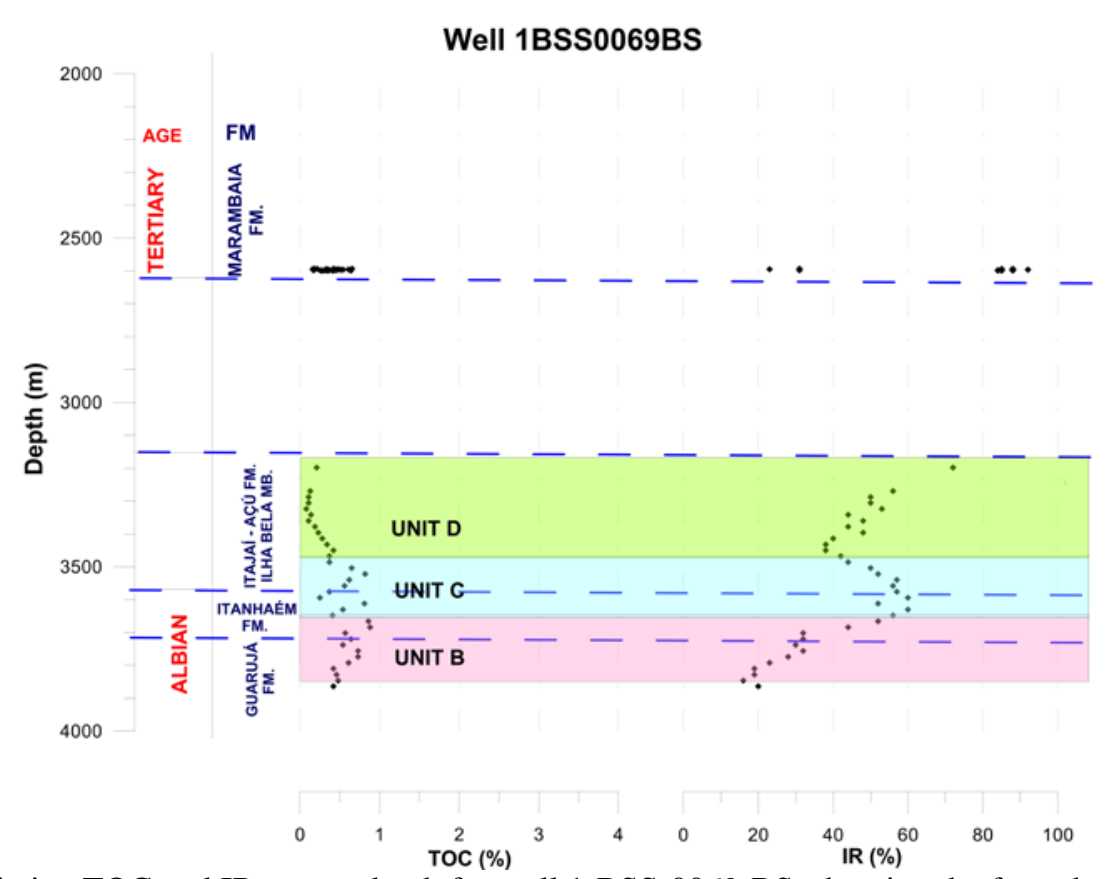

Figure 7 - Plot depicting TOC and IR versus depth for well 1-BSS-0069-BS, showing the four chemostratigraphic units identified.

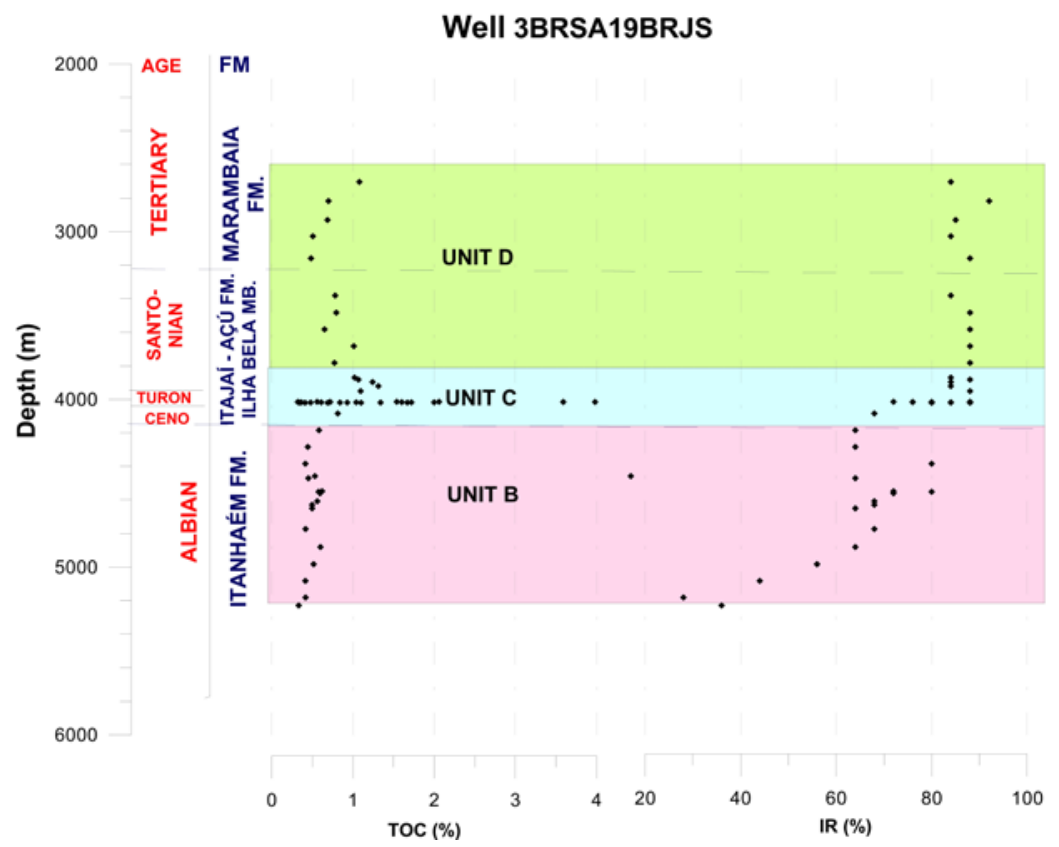

Figure 8- Plot depicting TOC and IR versus depth for well 3-BRSA-19B-RJS, showing the three chemostratigraphic units identified.

\section{Chemostratigraphic Unit C}

This chemostratigraphic unit, in most of the wells sampled, is inserted in the ItajaíAçú Fm., belonging to the Itajaí-Açu-Ilha Bela petroleum system, of Upper Cenomanian to Lower Santonian age. It probably corresponds to the global anoxic event of the base of the Turonian. It is notable because it exhibits the highest TOC values, varying from 0.5 to $2 \%$, reaching $4 \%$ in one sample, and IR values between $65 \%$ and $85 \%$. This unit is essentially a siliciclastic interval (Figures 5, 6, 7, 8, 9).
Chemostratigraphic Unit D

Unit D covers from the Itajaí-Açu Fm. To the Marambaia Fm. (Santonian-Oligocene), and exhibits TOC values between 0.5 and $1 \%$, and IR values from 70 to $90 \%$. This is unit is the most siliciclastic interval (Figures 5, 7, 8, 9).

\section{Type of Kerogen or Organic Matter}

Based on their respective van Krevelen diagrams type, for each chemostratigraphic unit it was possible to characterize the type of organic matter $(\mathrm{OM})$ present in the rock sample (Figures 11, 12, 13, 14). 


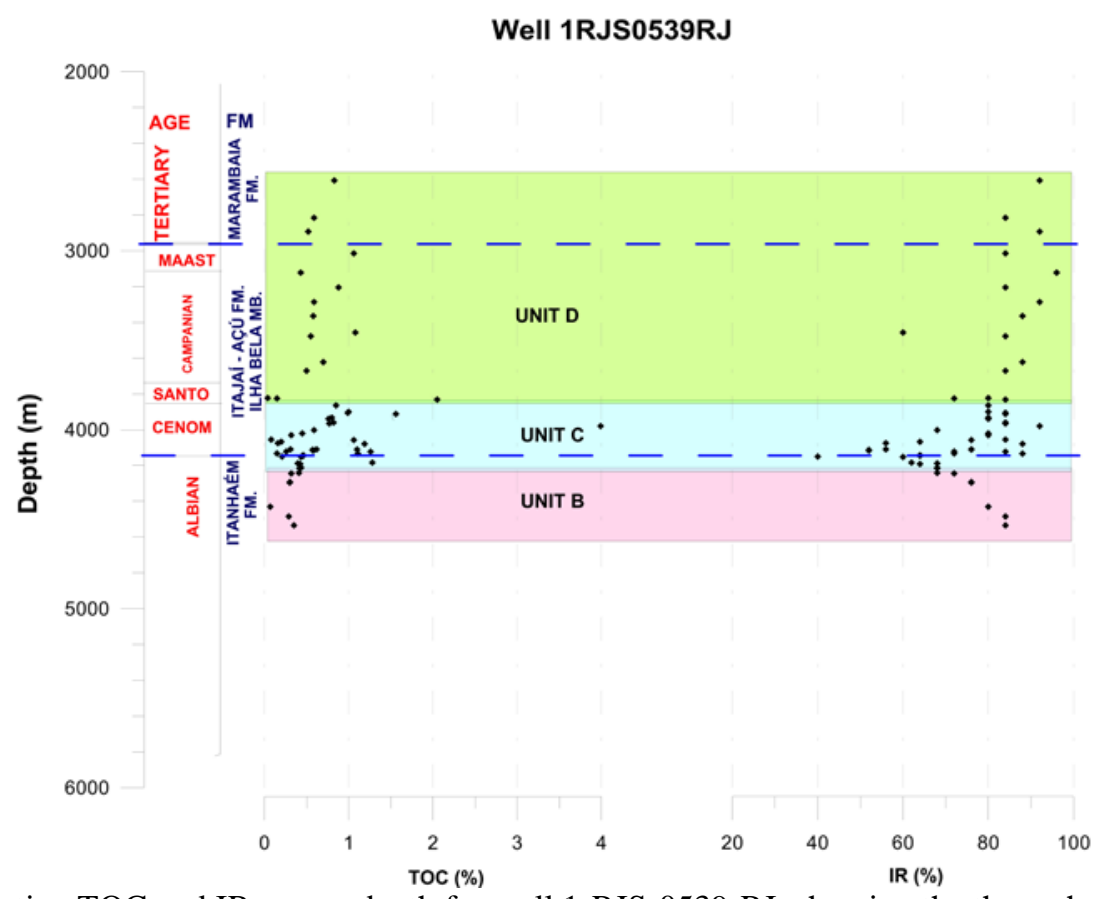

Figure 9 - Plot depicting TOC and IR versus depth for well 1-RJS-0539-RJ, showing the three chemostratigraphic units identified.

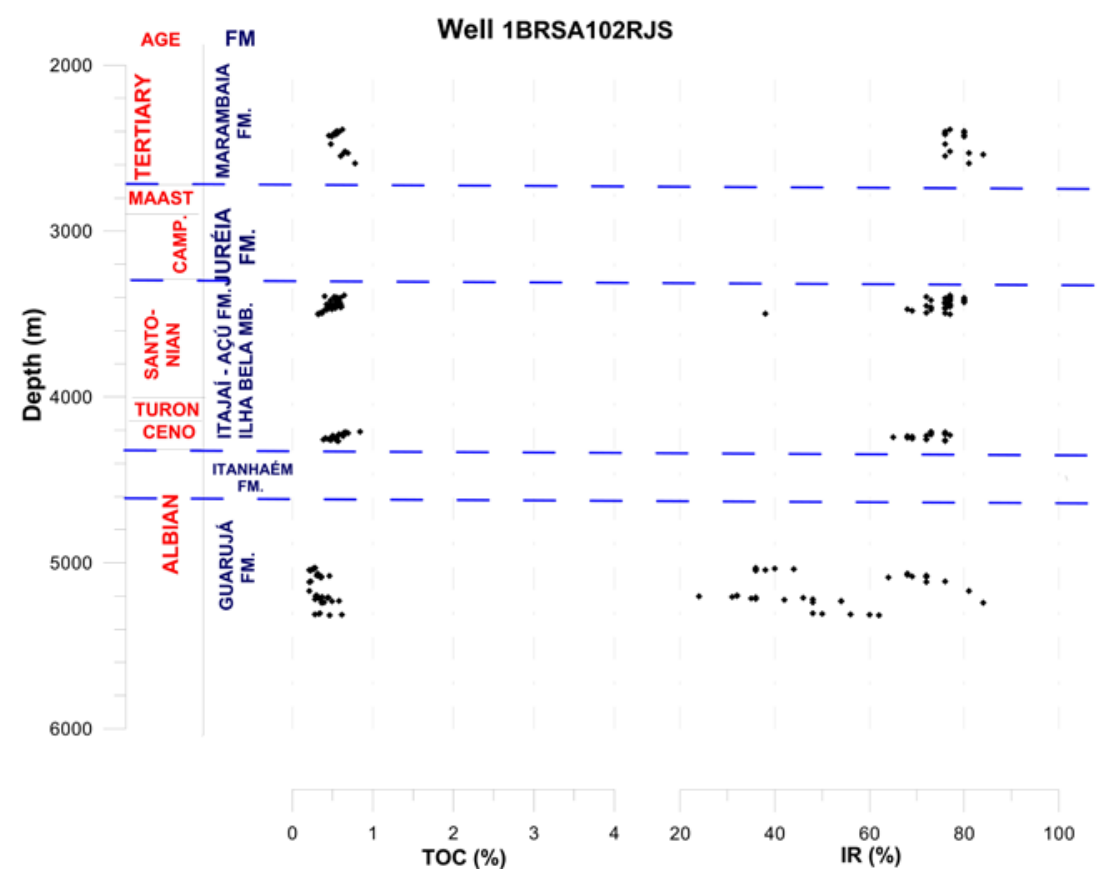

Figure 10 - Plot depicting TOC and IR versus depth for well 1-BRSA-102-RJS. It is not possible to identify and separate chemostratigraphic units.

The type of OM identified for In unit C, these values are between 20 and 440 chemostratigraphic units A and D was type III. In unit $\mathrm{A}$, the $\mathrm{HI}$ values varied from 120 to 340 $\mathrm{mgHC} / \mathrm{gTOC}$ and the OI values varied between 140 and $280 \mathrm{mgCO}_{2} / \mathrm{gTOC}$. For unit D, the HI and OI values are between 90 and 260 mgHC/gTOC, and between 100 and 300 $\mathrm{mgCO}_{2}$ /gTOC, respectively (Figures 11,14 ).

In chemostratigraphic units $\mathrm{B}$ and $\mathrm{C}$, there is a mixture of OM of type II/III, with HI values varying from 150 to $540 \mathrm{mgHC} / \mathrm{gTOC}$, and OI values varying from 30 to $300 \mathrm{mgCO}_{2} / \mathrm{gTOC}$. mgHC/gTOC for HI, and between 15 and 280 $\mathrm{mgCO}_{2} / \mathrm{gTOC}$ for OI (Figured 12, 13). In this last unit, some samples exhibit $\mathrm{HI}$ values < 40mgHC/gTOC, indicating that the OM from these samples suffered a very strong oxidation process.

\section{Generation Potential}

The pyrolysis analysis data (Figures 15 to 19), and the TOC versus $S_{2}$ ratios (Figure 20) of chemostratigraphic units $\mathrm{A}, \mathrm{B}, \mathrm{C}$ and $\mathrm{D}$ are shown below. 
In unit A, low TOC values, associated with low $\mathrm{S}_{2}$ values (generally below $2.0 \mathrm{mgHC} / \mathrm{g}$ rock), and HI below $300 \mathrm{mgHC} / \mathrm{g}$ TOC
(Figures 15, 16, 20), indicate that this unit predominantly exhibits a low potential for generating hydrocarbons.

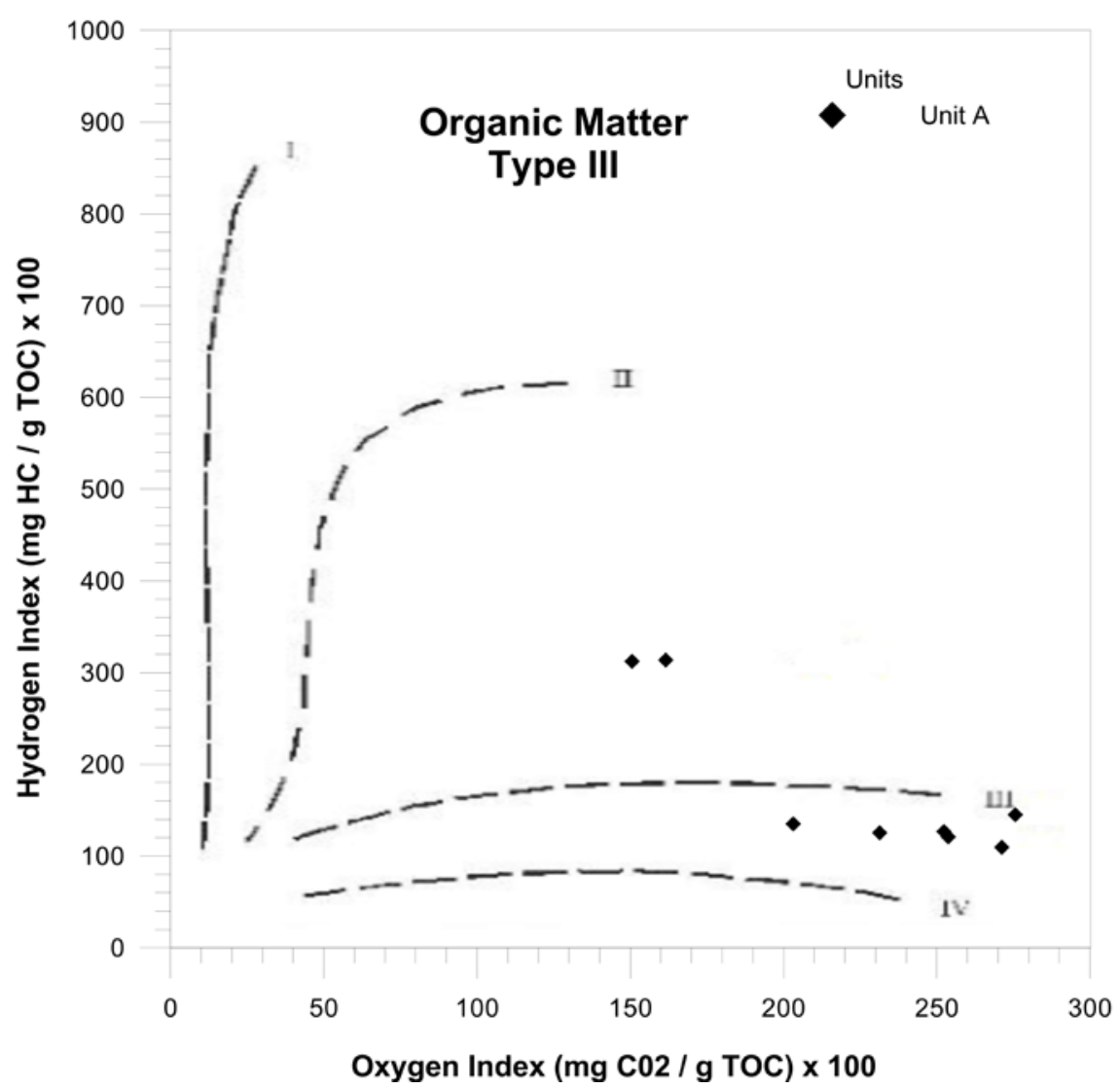

Figure 11 - Oxygen Index (OI) versus Hydrogen Index (HI), data from the van Krevelen diagram type for unit A.

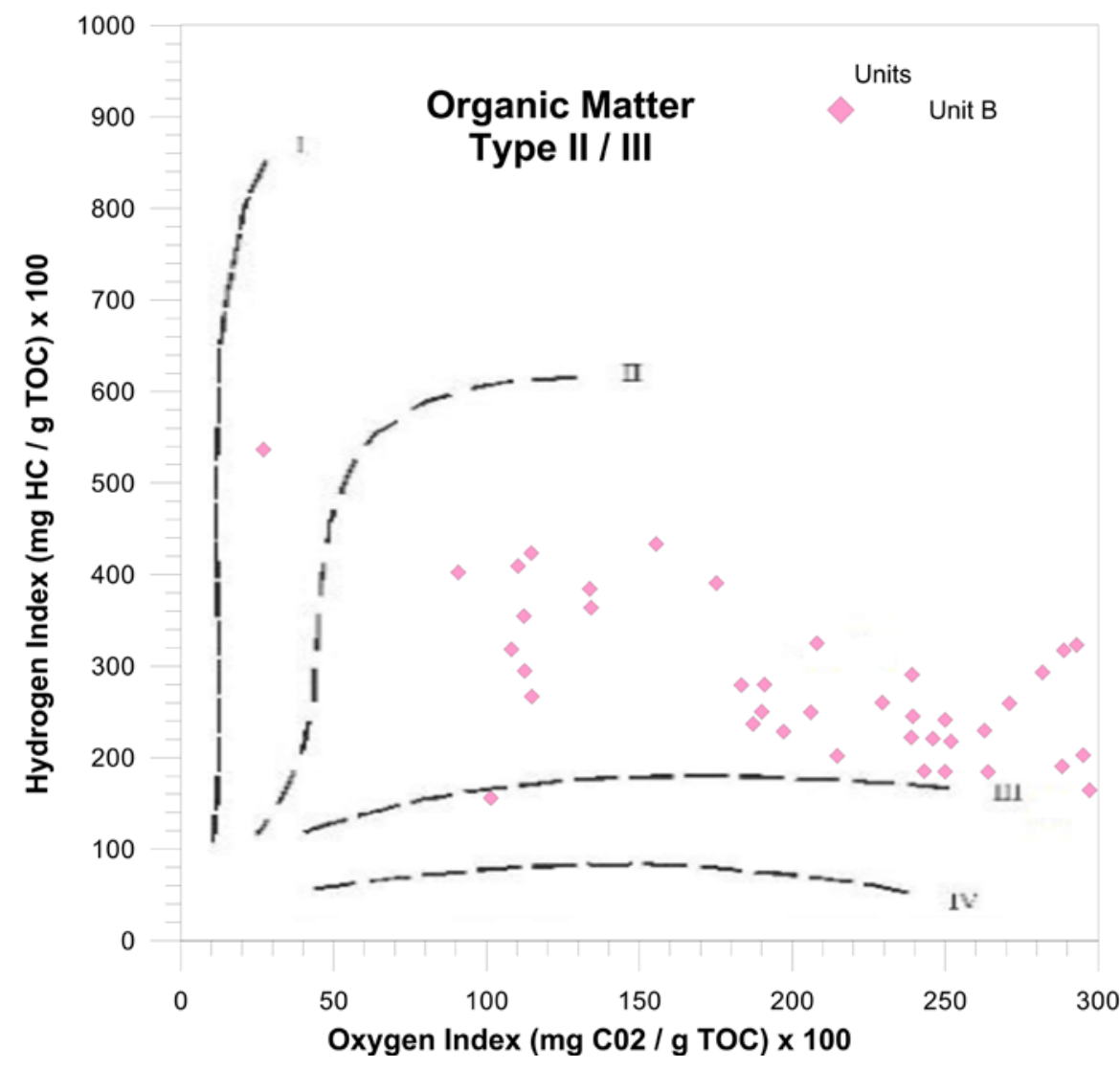

Figure 12 - Oxygen Index (OI) versus Hydrogen Index (HI), data from the van Krevelen diagram type for unit B. 


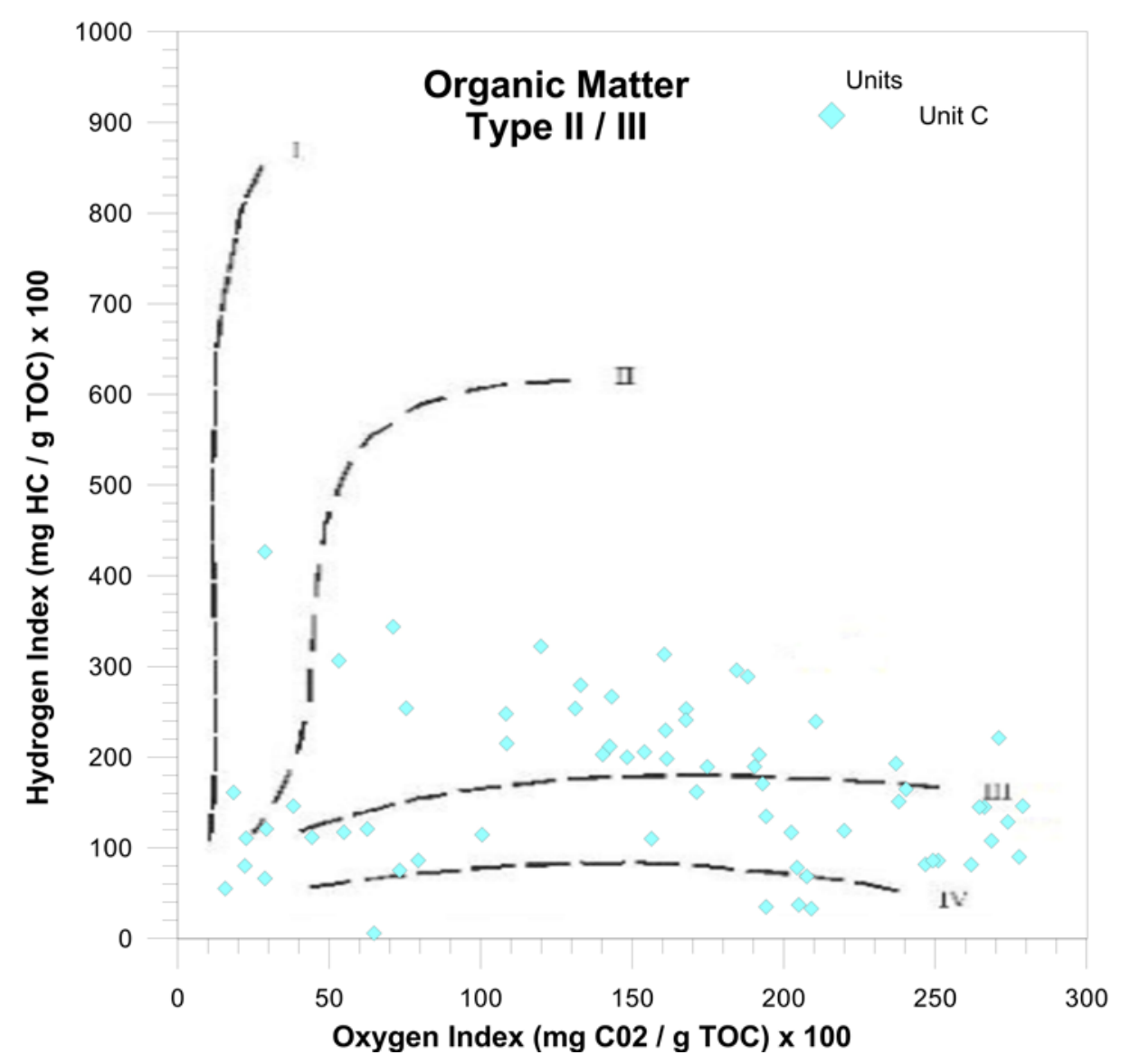

Figure 13 - Oxygen Index (OI) versus Hydrogen Index (HI), data from the van Krevelen diagram type for unit C.

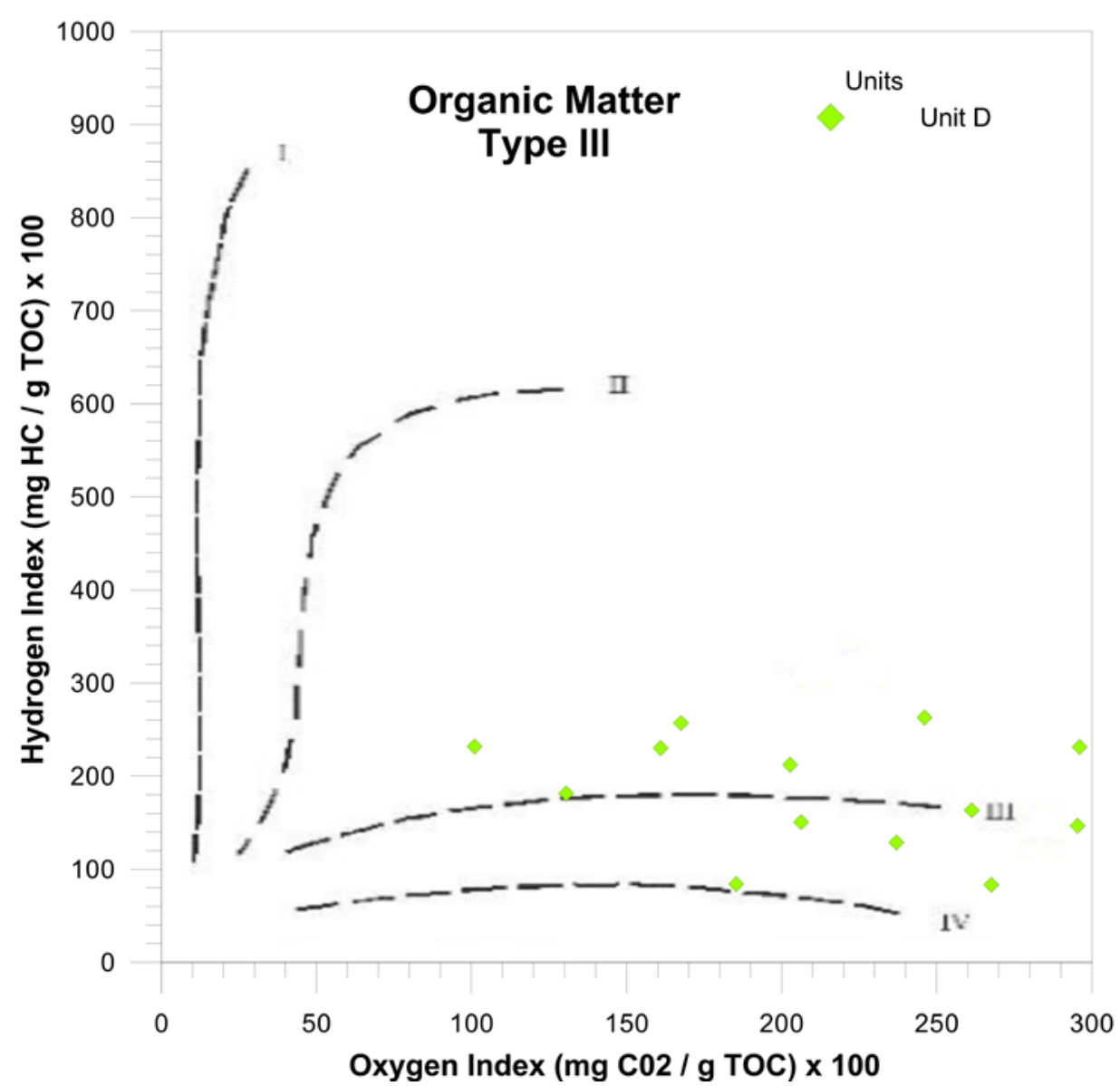

Figure 14 - Oxygen Index (OI) versus Hydrogen Index (HI), data from the van Krevelen diagram type for unit D. 


\section{Well 1BRSA74BRJS}

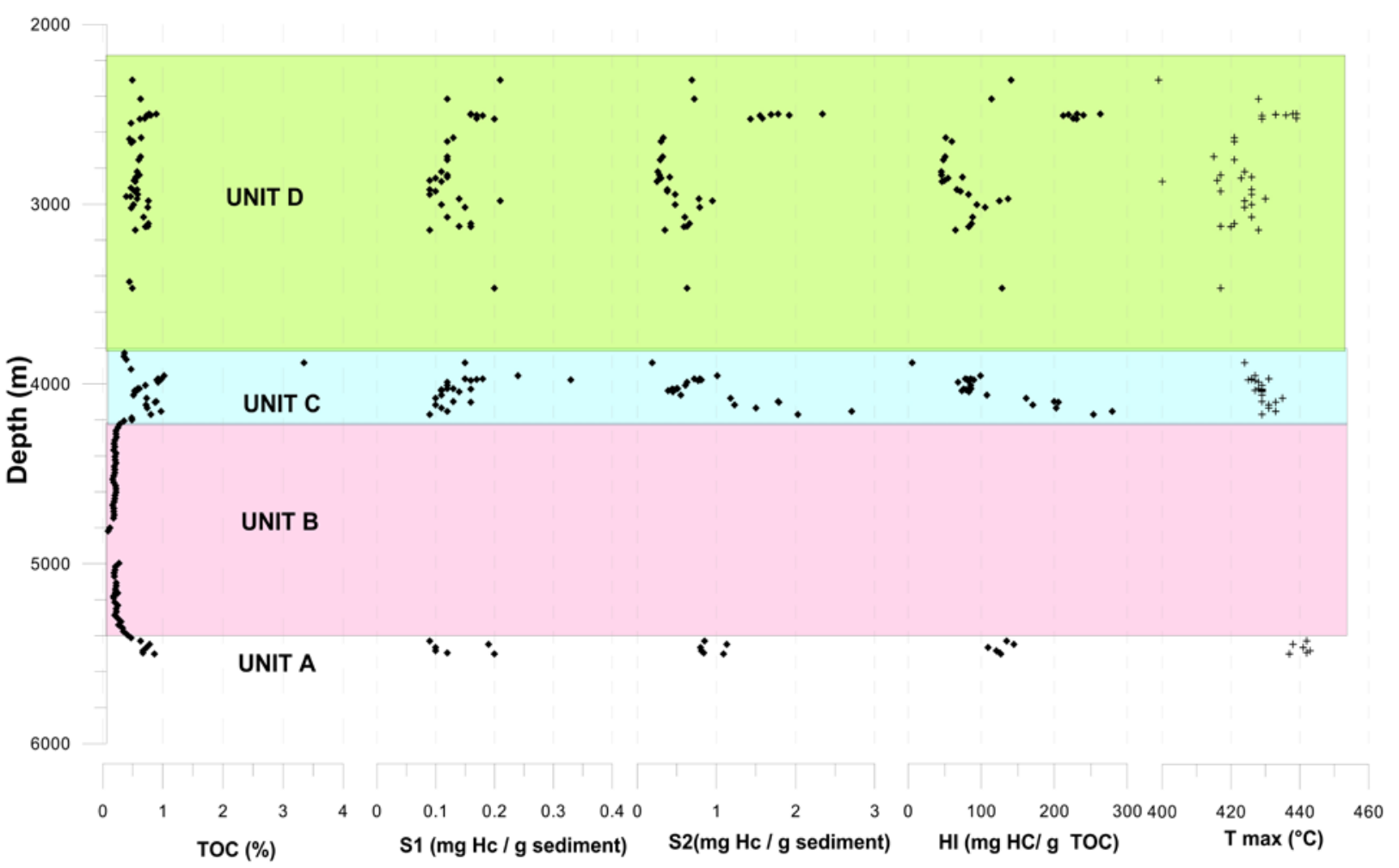

Figure 15 -Pyrolysis analysis plot of TOC versus depth data from well 1-BRSA-74B-RSJ, showing four chemostratigraphic units.

\section{Well 3BRSA2ARJS}

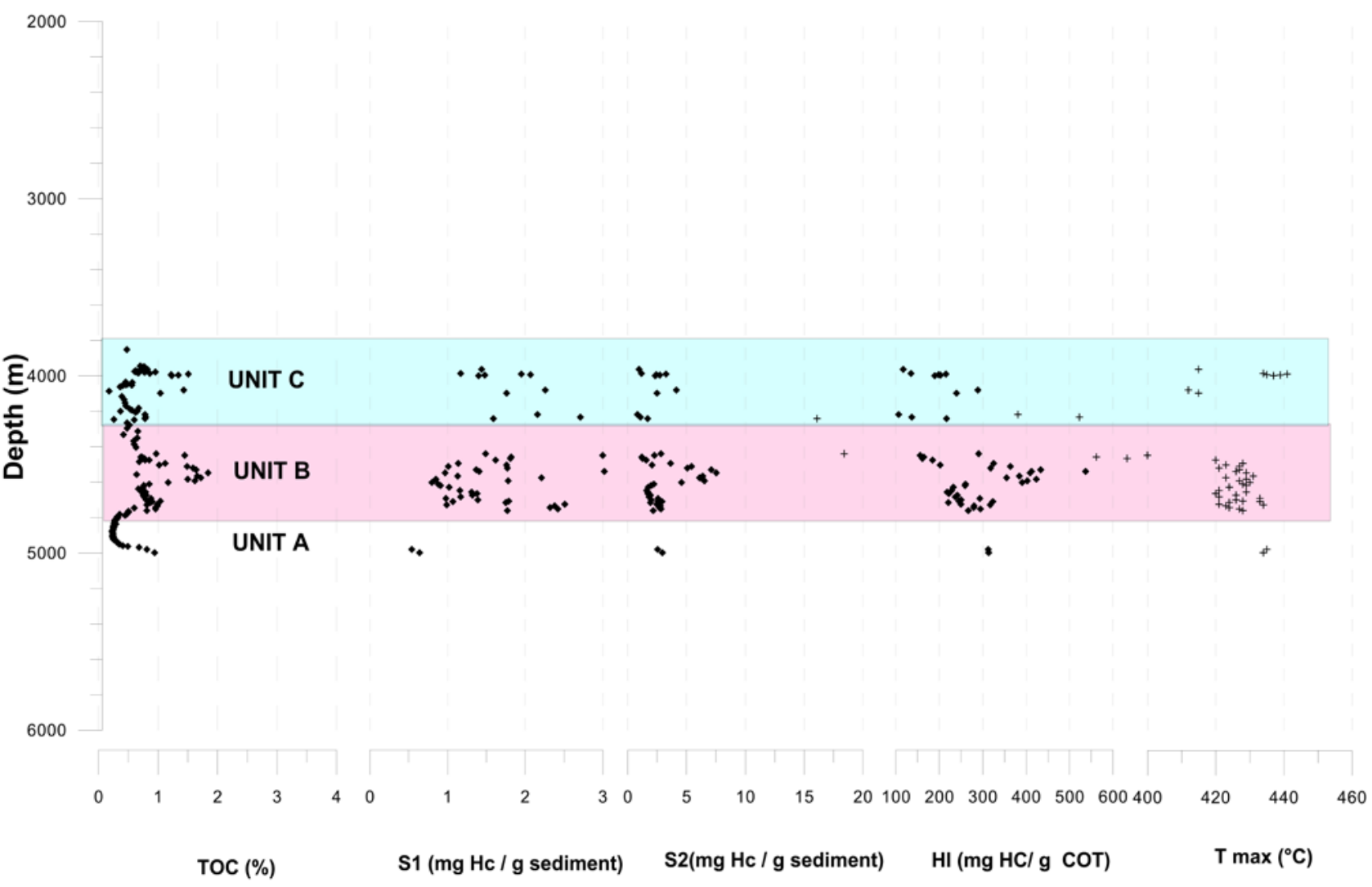

Figure 16 - Pyrolysis analysis plot of TOC versus depth data from well 3-BRSA-2A-RJS, showing three chemostratigraphic units. 


\section{Well 1BSS0069BS}

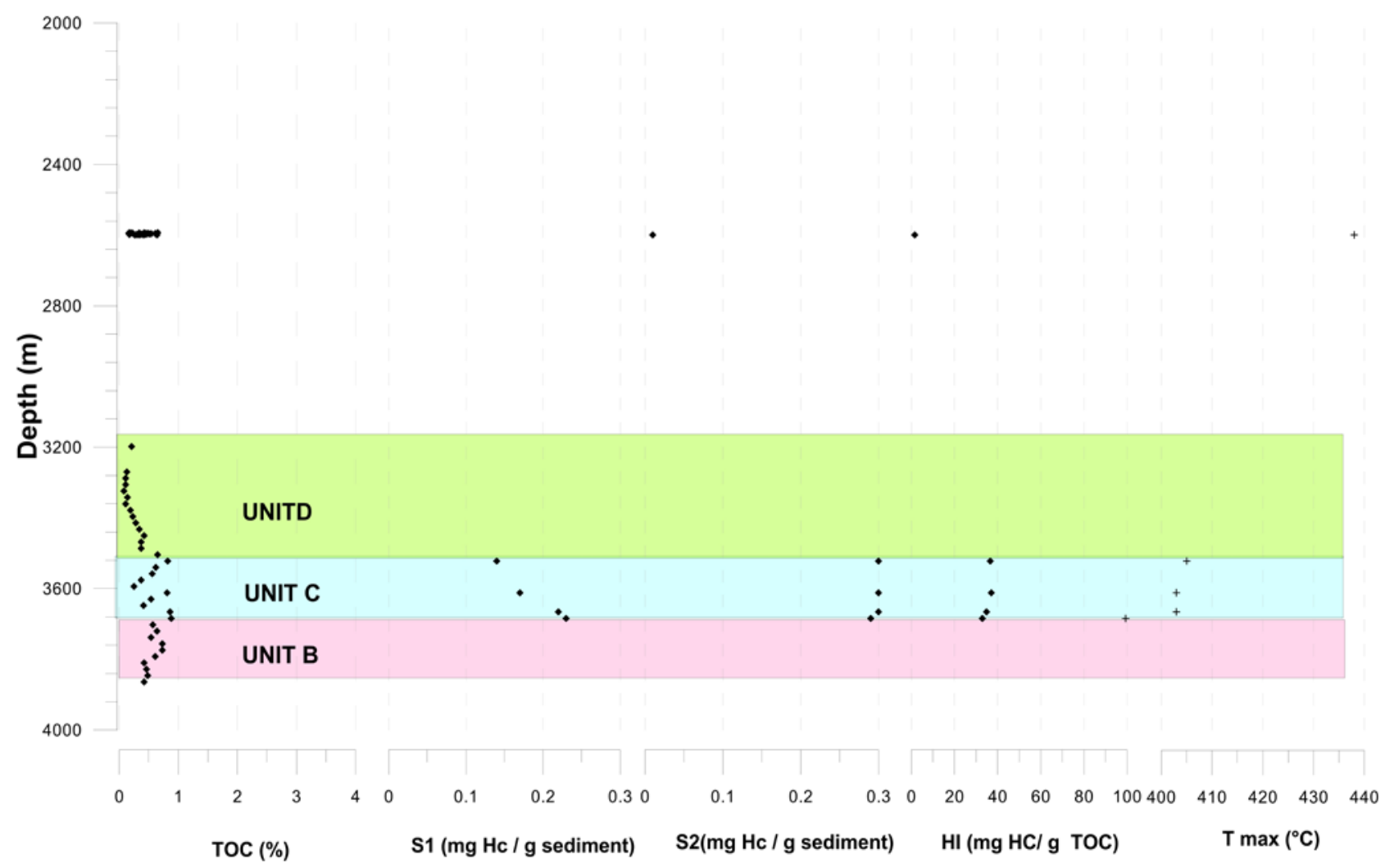

Figure 17 - Pyrolysis analysis plot of TOC versus depth data from well 1-BSS-0069-BS, showing three chemostratigraphic units.

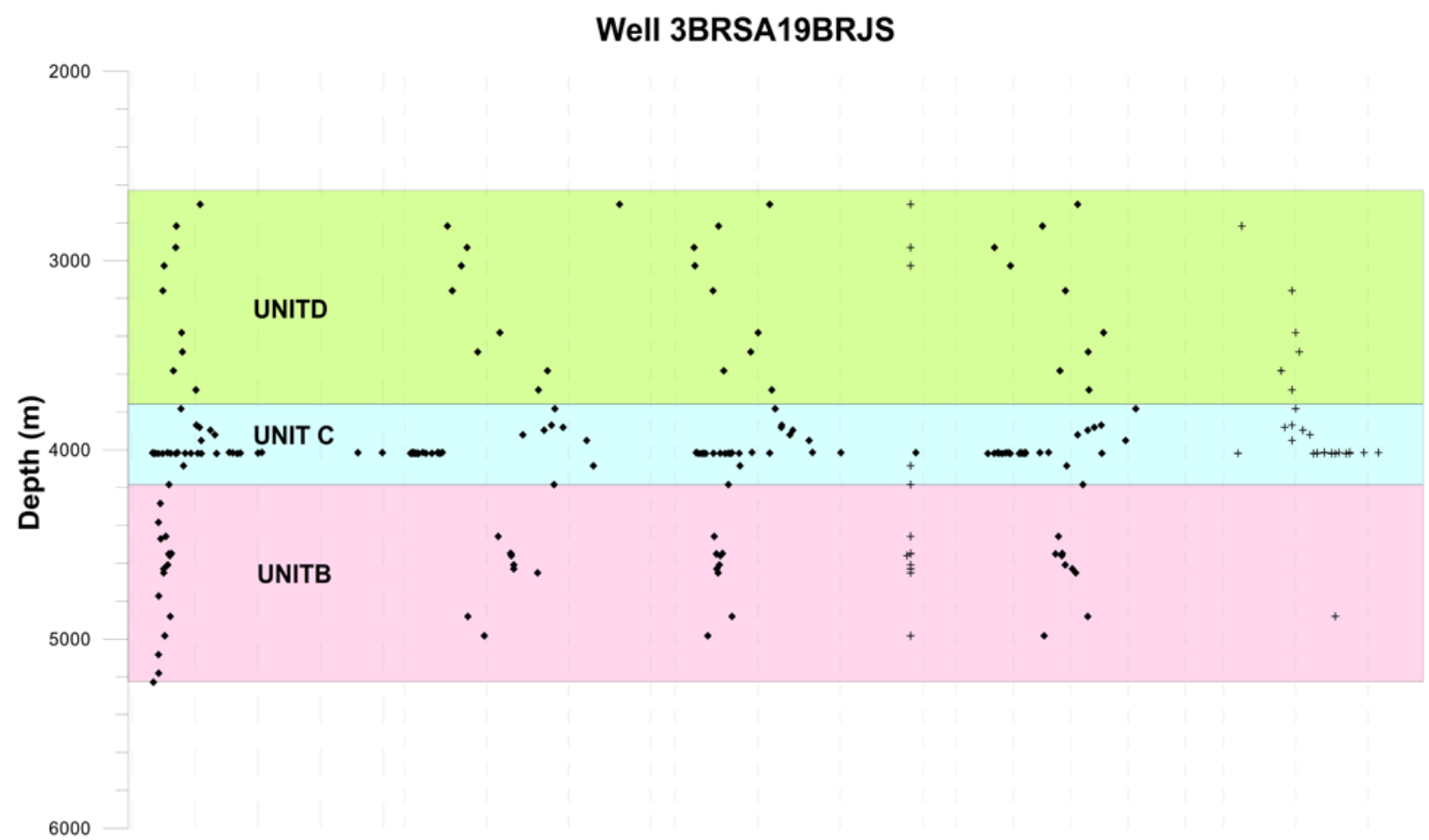

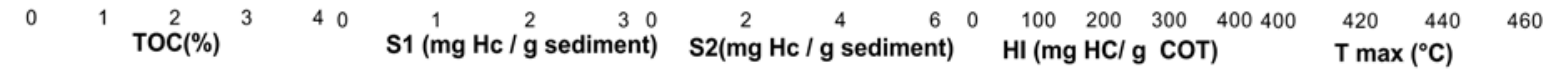

Figure 18 - Pyrolysis analysis plot of TOC versus depth data from well 3-BRSA-19B-RJS, showing three chemostratigraphic units. 


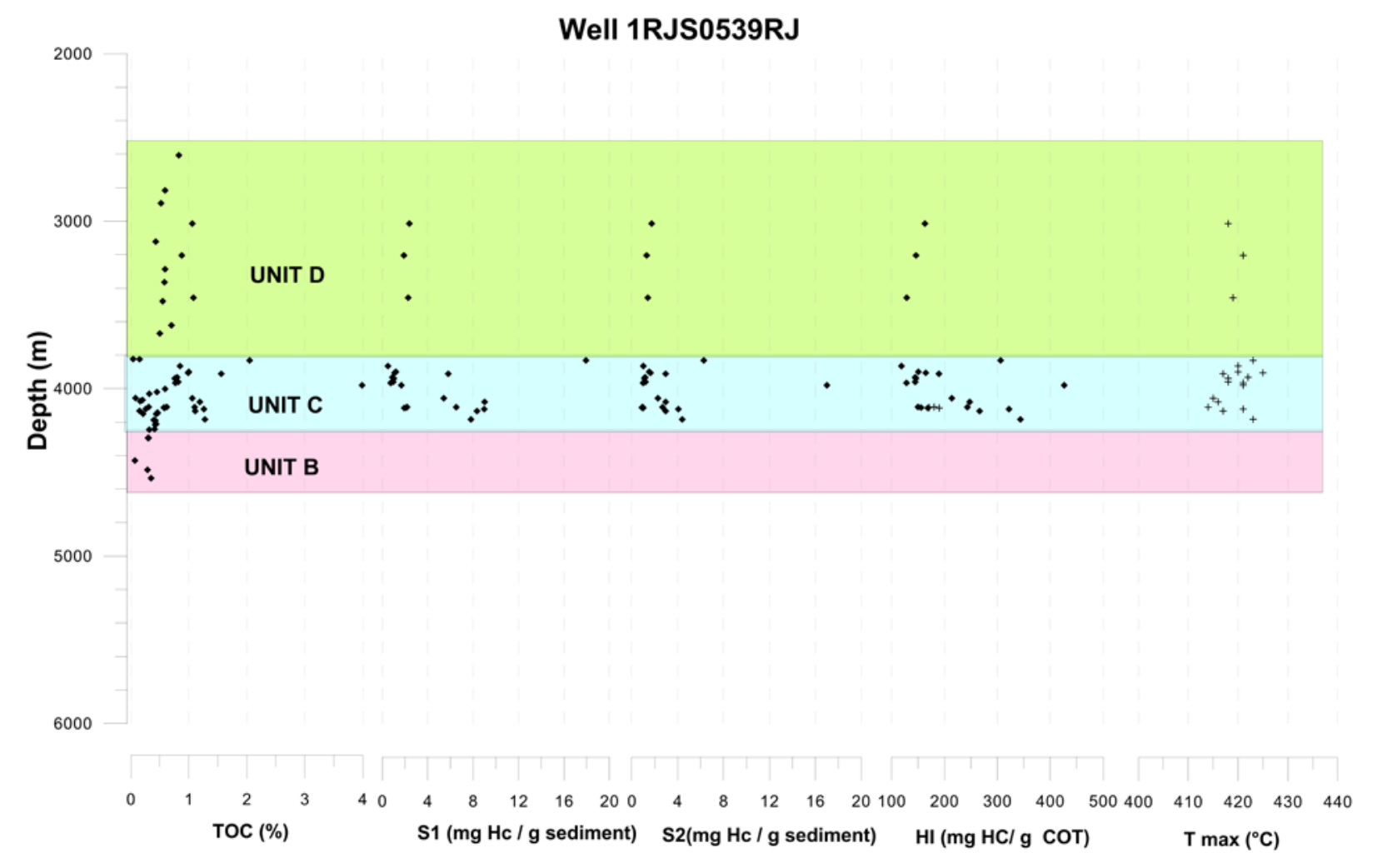

Figure 19 - Pyrolysis analysis plot of TOC versus depth data from well 1-RJS-0539-RJ, showing three chemostratigraphic units.

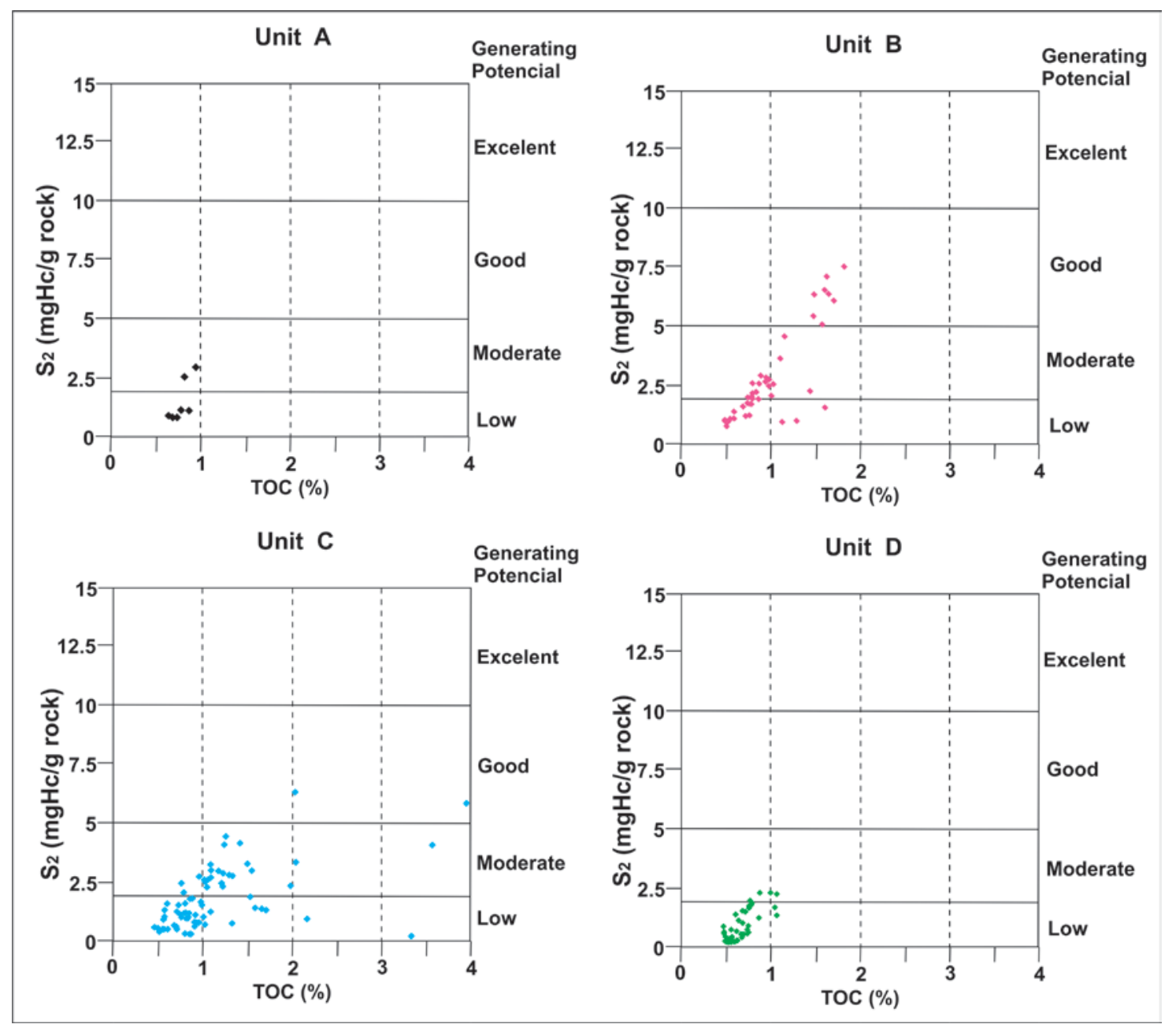

Figure 20 - Diagrams of $S_{2}$ versus TOC, which show the generation potential from the four chemostratigraphic units. 
Unit B, only in well 3-BRSA-2A-RJS, exhibited an interval with moderate to good generation potential for hydrocarbons (Figures 16, 20).

In unit $\mathrm{C}$, the $\mathrm{S} 2$ values indicate a low to moderate generation potential (Figura 20) for gas and condensate (Figures 15 to 19). In unit $\mathrm{D}, \mathrm{S}_{2}$ values between 0.2 and $2.2 \mathrm{mgHC} / \mathrm{g}$ rock, and $\mathrm{HI}$ values between 50 and $250 \mathrm{mgHC} / \mathrm{g}$ TOC, indicate allow potential for gas generation (Figures 18, 19, 20).

The analysis of the generation potential of the chemostratigraphic units suggests that units B (Albian) and C (Cenomanian/Turonian) could be of hydrocarbon generation interest, in some intervals.

\section{Maturation}

The thermal evolution of the $\mathrm{OM}$ was determined based on Tmax data obtained from pyrolysis analyses. In general, Tmax values were below $430^{\circ} \mathrm{C}$, indicating an immature stage of the OM in this study area. However, in a few isolated points it reaches the onset of oil generation window.

Analyzing the Tmax plots versus depth (Figure 21 and 22), for the chemostratigraphic units as well as for the wells, a projection of the initial oil generation window suggests that it would occur approximately at 5000m depth.

In this case, only unit A, which exhibited a low generation potential in the studied area, would have achieved sufficient thermal evolution for hydrocarbon generation. Units $\mathrm{B}$ and $\mathrm{C}$, which exhibit intervals with better generation potential, would be immature, but could achieve generation in deeper areas of the basin.

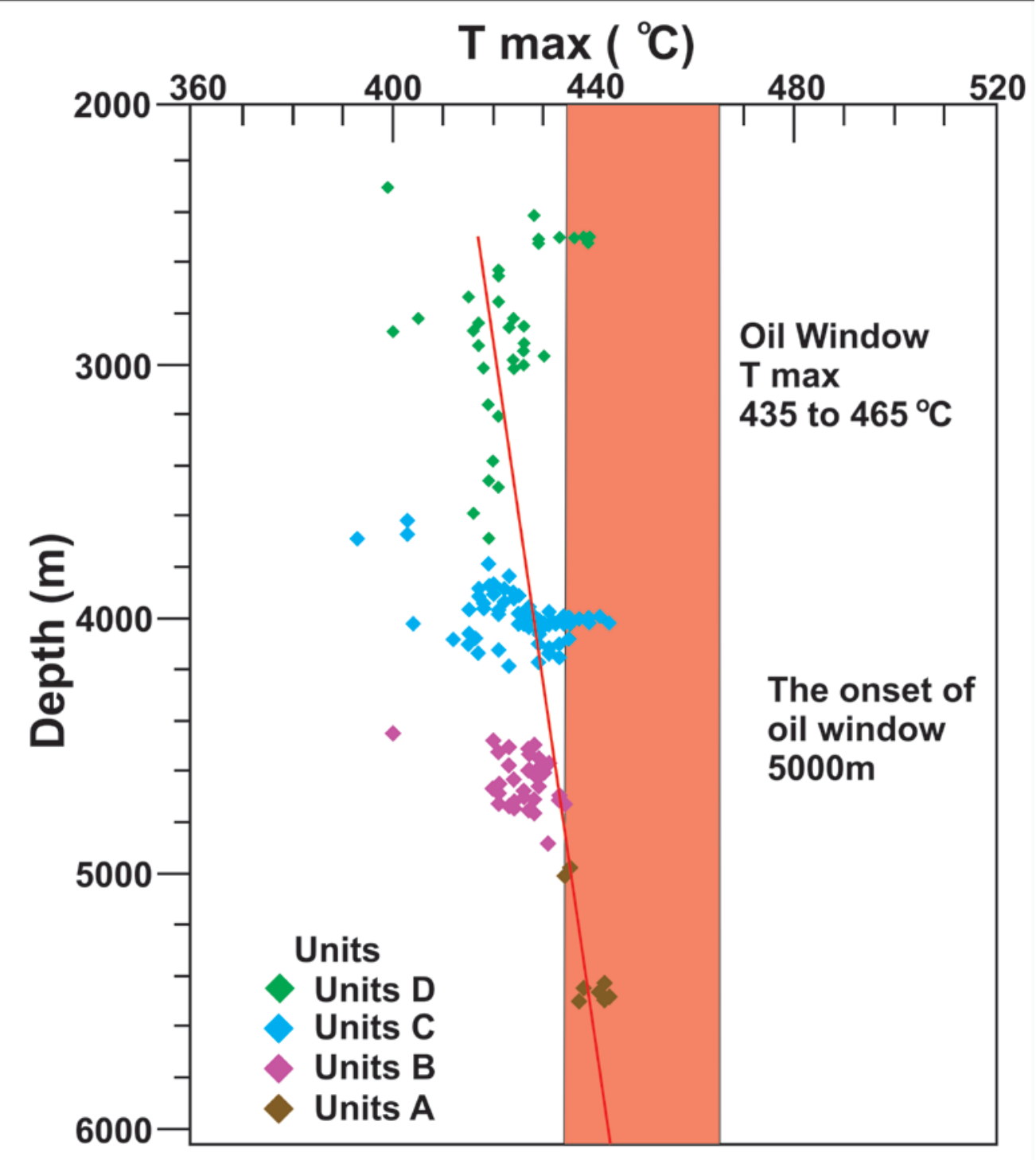

Figure 21 - Diagram of Tmax versus depth for the four chemostratigraphic units, showing the depth of the onset of oil generation window. 


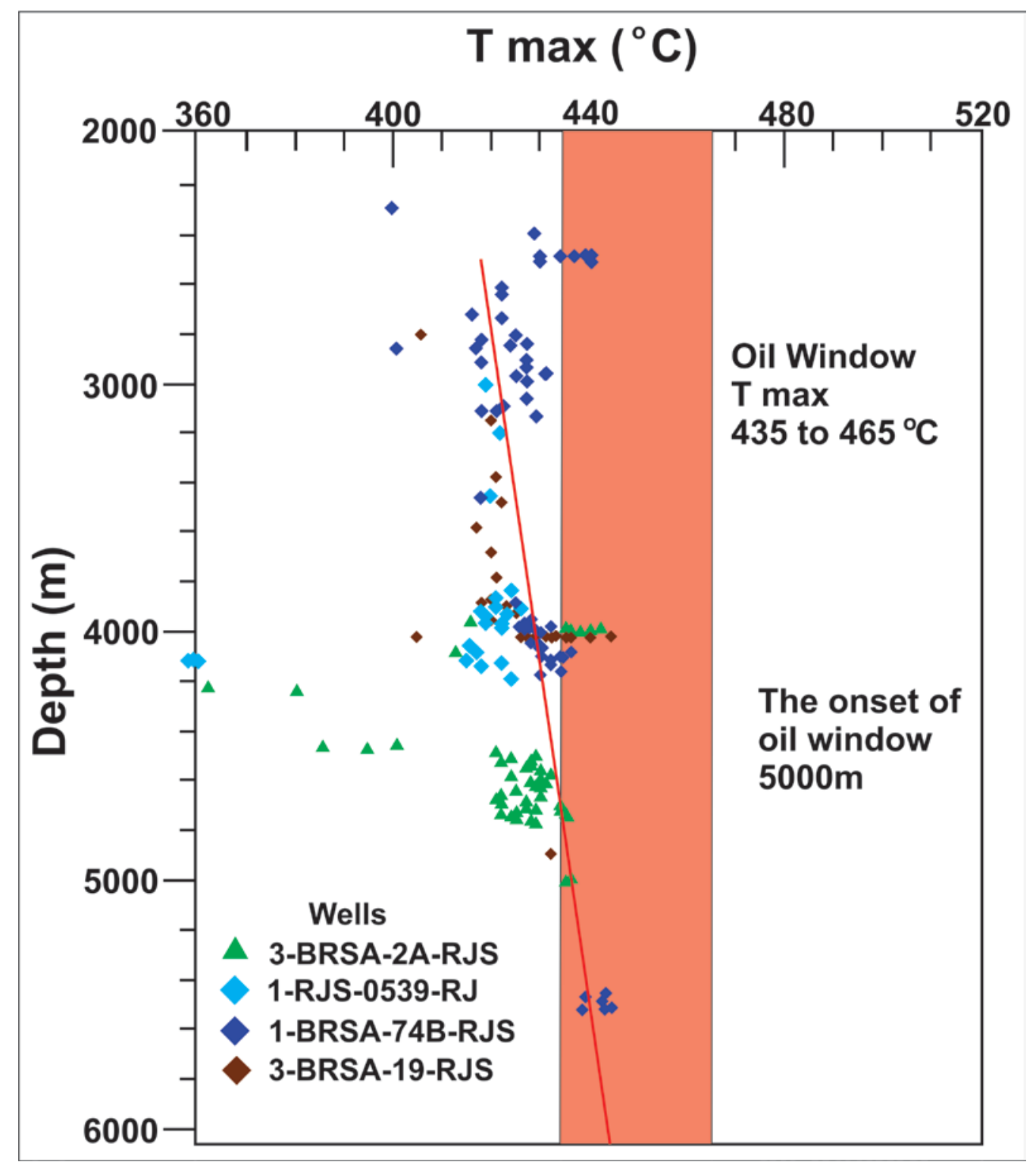

Figure 22 - Diagram of Tmax versus depth for five wells, showing the depth of onset of oil generation window.

\section{CONCLUSIONS}

In the six wells in the northern portion of the Santos Basin, assessed according to an organic geochemistry approach, and comprising the time interval from the Albian to the present, four chemostratigraphic units (A, B, C and D) were identified.

The kerogen present is of type III (units A and D), and a mixture of kerogen of type III and II (units B and C).

Units A and D exhibit low or no hydrocarbon generation potential, regarding quantity and quality of the organic matter. Units B and C could have some hydrocarbon generation potential, however not conclusively, due to insufficient data, and the low sample representativeness within these units. The occurrence of units B and $\mathrm{C}$ with more overburden, in this portion of the basin, could possibly reach the onset of hydrocarbon generation, since the oil window is a temperature dependant interval.

In relation to thermal evolution of the organic matter, the sedimentary package reaches the generation window at an estimated depth of $5000 \mathrm{~m}$. In this portion of the basin, hydrocarbon generation would have to be associated with deeper source rocks.

\section{ACKNOWLEDGMENTS}

This work received the invaluable support of the State University of Rio de Janeiro, the Graduate Course "Basin Analysis Project", ANP (Agência Nacional de Petróleo, Gás Natural e Biocombustíveis), Statoil Brasil, and the translation and revision of Dr. Cleveland M. Jones. 


\section{REFERENCES}

CHANG, H. K., KOWSMANN, R. O., FIGUEIREDO, A. M. F. New concepts on the development of East Brazilian marginal basins. In: RAJA GABAGLIA, G.P. \& MILANI, E.J. (eds) Origem e evolução das bacias sedimentares. Rio de Janeiro. Petrobras, p. 269-289, 1990.

CHANG, H. K., ASSINE, M. L., CORRÊA, F. S., TINEN, J. S., VIDAL, A. C., KOIKE, L. Sistemas petrolíferos e modelos de acumulação de hidrocarbonetos na Bacia de Santos. Revista Brasileira de Geologia, v. 38, n. 2, p. 29-46, 2008.

ESPITALIÉ, J., DEROD, M., MARQUIS, F. La pyrolyse Rock-Eval et ses applications. Revue de I'Institut Français du Pétrole, v. 40, p. 755-784, 1985.

ESPITALIÉ, J., LAPORTE, J. L., MADEC, M., MARQUIS, F., LEPLAT, P., PAULET, J. Méthod rapide de charactérization des roches mères, de leur potentiel pétrolier et de leur degré d'évolution. Revue de I'Institut Français du Pétrole, v. 32, p.23-43, 1977.

MACEDO, J. M. Evolução tectônica da Bacia de Santos e áreas continentais adjacentes. Boletim de Geociências da Petrobras, v. 3, n. 3, p. 159-173,1989.

MOHRIAK, W. U. Bacias sedimentares da margem continental brasileira. In: BIZZI, L.A., SCHOBBENHAUS C., VIDOTTI R.M., GONÇALVES J.H. (editors) Geologia, Tectônica e Recursos Minerais do Brasil. Brasília: Companhia de Pesquisa e Recursos Minerais, p. 87-165. 2003.
MOREIRA, J. L. P., MADEIRA, C. V., GIL, J. A., MACHADO, M. A. P. Bacia de Santos. Rio de Janeiro. Boletim de Geociências da Petrobras, v. 15, n. 2, p. 531549,2007.

PEREIRA, M. J., BARBOSA, C. M., AGRA, J., GOMES, J. B., SAITO, M., RAMOS, M. A., CARVALHO, M. D., STAMATO, M., SÁ O. A. R. Estratigrafia da Bacia de Santos: análise das sequências, sistemas deposicionais e revisão litoestratigráfica. In: CONGRESO BRASILEIRO DE GEOLOGIA, 34, 1986, Goiânia, Anais...Goiânia, Sociedade Brasileira de Geologia, 1986, v. 1, p. 65-79.

PEREIRA, M. J. \& MACEDO, J. M. A Bacia de Santos: perspectivas de uma nova província petrolífera na plataforma continental sudeste brasileira. Boletim Geociências da Petrobrás, v. 4, n. 1, p. 3-11, 1990.

PETERS, K. E. \& CASSA, M. R. Applied source rock geochemistry, In: MAGOON, L. B. \& DOW, W. G. (editors), The Petroleum System - From Source to Trap: The American Association of Petroleum Geologist, Memoir 60, p. 93-120, 1994.

TISSOT B. P. \& WELTE D. H. (Editors). Petroleum Formation and Occurrence. 2 ed. Springer-Verlag, Berlin, Heildelberg, 699p, 1984.

Submetido em 11 de julho de 2016 Aceito em 3 de novembro de 2016 